$\frac{\text { DE }}{\mathrm{G}}{ }^{\text {DE GRUYTER }}$

\title{
ARE CULTURAL AND GENDER DIVERSITY DRIVERS OF FIRM PERFORMANCE IN POST- CRISES EMERGENT ECONOMIES?
}

\author{
Silvia SUMEDREA* \\ Transilvania University of Brasov, Romania
}

\begin{abstract}
The study aims to see if it could offer a positive response to the question whether the company's financial performance depends on diversity of ownership structure, board and management team. Studies of this type have been made in the developed financial markets, but hardly any were made in recent years in emerging markets. The results of this study on the Romanian financial market indicate that relationships between ownership structure, board and management team composition and firm performance are mixed. ROA, ROE, ROS and P/BV as measures of firm performance are influenced by the presence of foreign shareholders, top foreign managers, and the percentage of women managers and by company's size. Boards including foreign members are more inclined to appoint foreign managers and women in firm's managerial teams, but a small number of such persons are not positively associated with an increased financial performance of the firm.
\end{abstract}

JEL Classification: C10, G34, M14, L25, M21

Keywords: corporate governance, diversity, firm performance, business economics, econometrics

\section{Introduction}

In a world weakened by the crisis, galvanized by disruptive innovations and increasingly interconnected, companies are constantly looking for new elements that foster their competitive advantages and allow them to achieve business performance. Post-crisis evolution of world economy has experienced an interesting dynamic, distorted

\footnotetext{
${ }^{*}$ Corresponding author. Address: Faculty of Economic Studies and Business Administration, Transilvania University of Brasov, 1, Colina Universitatii str., A building, Illrd Floor, Brasov, Romania, Tel. +40742 133341, Email: silvia.sumedrea@unitbv.ro
} 
by numerous technological and social innovations and political events. The explosive development of communications technology has revealed an unprecedented interconnection of all economic actors in a global world, where more and more detailed information on competitors, customers, markets and alternative products are available. The most recent political and social changes (mainly related to migration and the EU future status) have also contributed to changing perceptions about how stakeholders judge growth opportunities and business risks. Under these circumstances, there is an emerging theory that a more diverse ownership, board and management team can contribute to improve a sustainable development of the firm's business.

The company's shareholders are the first interested in its performance, the shareholding structure reflecting the structure of control over the company and its development. This paper seeks to determine how and if cultural diverse sources of capital shareholding (foreign versus Romanian shareholders) can influence firm performance. The paper also examines to what extent the structure of the board of directors (as representatives of shareholders) contribute to increasing the performance of the company. Studies have generally examined the following characteristics of boards: the size of the board, proportion of outsiders on the board, the number of board meetings and the women directors proportion (Chidambaran et al., 2006), the present work analysing also the cultural background of the shareholders and directors, according to area of origin. Directing the company's development and shaping its strategies are responsibilities of the board of directors and decisions taken by these underlying performance of the company, but as for conducting current operations, the board appoints a management team, and this team will put into practice the vision and goals strategic formulated by board. The paper examines possible link between the diversity of the management team and the company performance, particularly if performance improves when the management team is heterogeneous in terms of cultural and gender-makers.

\section{Literature review}

Although the concept is a very commonly used, there is no universally accepted definition of firm performance. Some authors consider it as a concept related to the effective use of human resources (Huselid et al., 1997), while others, more recently, consider it a subjective and multidimensional concept (Santos and Brito, 2012), or having multiple facets: quantitative and qualitative; strategic, financial (in terms of income or sales) and operational (in terms of loyalty and customer satisfaction, product quality, company reputation) (Fitzsimmons et al., 2005). Concerns regarding the shareholding structure and its influence on company performance have been the subject of studies, mainly on the American market, and nowadays, evidences are coming from the European market (Claessens and Tzioumis, 2006), but massively from emerging African or Asian markets such as China (Cull, Xu, 2005), Turkey (Aydin et al., 2007), Indonesia (Abukosim et al., 2014), Ghana (Darko et al., 2016).

In Romania, a study by Vintilă and Gherghina (2015) looked at the link between ownership structure and firm performance in 2007-2011, but found no significant link between them, the shareholding structure being analysed only in terms of the type of shareholders (i.e. insiders, companies from financial intermediation sector, states and employees' organizations), but not in terms of the origin of capital. Previously, 
in 2013, the same authors studied the relationship between board of directors' independence and firm value, which resulted in a positive influence of the percentage of independent directors on firm value, but down to a threshold of their representation of $47.23 \%$, whereupon their influence becomes negative. Another paper that studied data on Romanian market, referring specifically to banking companies, showed only the links between corporate performance and CEO duality (Moscu, 2015).

Worldwide, as shareholders of companies separated from management, there have been developed researches into performance objectives of managers, as there were observed conflicts between shareholders' and managers interests, because managers rather pursued maximizing sales than profits (Baumol, 1959, Cyert and March, 1963). As a result, various features of the board and management teams began to be studied: board diversity, size, proportion of outsiders on the board, number of board meetings and performance (Jensen, 1993, Carter et al., 2003, Erhardt et al., 2003).

Generally speaking, there are two different approaches in terms of group diversity and performance: on one hand, diversity leads to a greater knowledge base, creativity and innovation, and therefore, becomes a competitive advantage (Richard, 2000; Roberge and van Dick, 2010). The keys to improved performance are integration and communication. Such groups easily cope with organizational and market changes. The board is making its decisions during board meetings and some authors consider that firm performance can be explained also by using board meetings as an explicative variable (Julizaerma and Sori, 2012; Rodriguez-Dominguez et al., 2012). On the other hand, diversity can potentially be a disadvantage in terms of group performance; mixed teams were slower in their activities and reactions and less likely than similar teams to respond to rivals' initiatives. Diverse team members tend to be more involved in conflict situations (van Knippenberg and Schippers, 2007, Zhen Zeng, 2011). More recently, Ferreira and Kirchmaier (2013) compared data for 22 European countries and discovered that good governance depends by country characteristics. The cultural variables as possible drivers of firm performance were first brought to attention in the 1980s, when Hofstede published his work on culture's consequences and the international differences in work-related values (Hofstede, 1983). As a result, an abundant literature is now supporting the idea that organizational culture is important in understanding firm performance. In a supplementary effort to better understand the complex world that we live in, more recent studies brought into attention additional drivers of firm performance, such as the type of operational processes of companies, and demonstrating that being eco or non-eco-friendly in the operational processes really counts. (Lin et al., 2015).

\section{Research methodology}

The paper's aim is to explore the existence of links between the diversity of the management team and the company performance in case of heterogeneous shareholder groups and management boards and teams, where heterogeneity will be expressed in terms of gender, cultural background and independence. For that purpose, the following hypothesis will be tested: 
1. A direct relationship exists between financial performance and a diverse cultural shareholder structure.

2. A direct relationship exists between financial performance and a diverse cultural board.

3. A direct relationship exists between financial performance and board independence.

4. A positive relationship exists between financial performance and gender diverse board.

5. A positive relationship exists between financial performance and cultural diverse management teams.

6. A positive relationship exists between financial performance and gender diverse management team.

The data for the study were gathered from the main Romanian companies listed at Bucharest Stock Exchange (BSE), and panel data analysis covering the 2014-2015 period of time has been used. According to Torres-Reyna (2007) "panel data (also known as longitudinal or cross-sectional time-series data) is a dataset in which the behaviours of entities are observed across time.[...] Panel data allows you to control for variables you cannot observe or measure like cultural factors or difference in business practices across companies". To test the above mentioned hypothesis, first a descriptive statistic was performed, followed by a correlation analysis and a general linear regression model (see equation (1)).

The regression model is aimed at discovering the possible links between the financial performance as the dependent variable $(Y)$ and other 10 independent and control variables (X1 to X10). The company's performance has been expressed as being the return on assets ratio (ROA), return on sales ratio (ROS), return on equity ratio $(R O E)$ and, finally, as the price to book ratio $(P / V)$. The independent and control variables $(\mathrm{X} 1$ to $\mathrm{X} 10)$ are included in table 1 and explained further on.

$$
Y=\alpha+\beta_{1} X_{1}+\beta_{2} X_{2}+\beta_{3} X_{3}+\beta_{4} X_{4}+\beta_{5} X_{5}+\beta_{6} X_{6}+\beta_{7} X_{7}+\beta_{8} X_{8}+\beta_{9} X_{9}+\beta_{10} X_{10}+\xi_{i}
$$

Table 1. Description of variables

\begin{tabular}{|l|l|}
\hline Variable type & Description \\
\hline Dependent variables & \\
ROA = EBIT/total assets & Return on assets \\
ROE= Net income/Common equity & Return on equity \\
ROS = Net income/Net sales & Return on sales \\
P/BV= Market capitalization/ & Price to book ratio \\
Book value of company & \\
\hline Independent variables & \\
X1 - FRN_SHL & Proportion of foreign shareholders \\
X2 - FRN_BRD & Proportion of foreigners in board \\
\hline
\end{tabular}




\begin{tabular}{|l|l|}
\hline Variable type & Description \\
\hline X3 - EXEC_BRD & Percentage of executive members of \\
X4 - WOM_BRD & board \\
X5 - FRN_MN & Ratio of women in board \\
X6 - WOM_MN & Ratio of foreigners in management team \\
X9 - MEET & Ratio of women in top management team \\
X10 - ENV & Number of annual board meetings \\
& Type of company's operational process \\
\hline Control variables & \\
X7 - SIZE & Log (Net sales), size of the company \\
X8 - AGE & Years in business for the company \\
\hline
\end{tabular}

Data of listed companies were used because those companies must comply with the obligation to publicly disclose detailed information about their board and management team structure, along with detailed reports on financial data, as it is stipulated in the BSE Code of Corporate Governance. The analysed data set contain detailed information gathered from the premium and first tier companies, belonging to different industrial sectors: mining and quarrying, manufacturing (food, drinks, textile, paper, machineries, pharmaceutical, etc.), electricity, gas, steam and air conditioning production and supply, construction, wholesale and retail, transport and storage, hotels and restaurants, real estate activities and financial intermediation and insurance domain. Initially all the 84 listed companies were considered, because they systematically reported data related to corporate governance beginning only with 2014. After a preliminary analyse, all 13 listed companies in financial intermediation and insurance domain were excluded, because of their specificity in disclosing their financial data. Another 10 companies experiencing various litigations (being under special judicial procedures) were excluded also, and other three were disqualified for data incompatibility (one company was listed in the last part of 2014, and the other two experienced negative equity and losses and some financial ratios such as ROE would be misinterpreted). As a result, data of 58 companies covering 20142015 period of time were considered for this study and the data were collected from various sources: the BSE website (www.bvb.ro), the Ministry of Finance website (www.mfinante.ro), companies annual board reports, balance sheets, income statements, financial auditors' reports and companies' websites.

First, for each company, data related to their domain of activity, number of years in business and ownership structure (Romanian versus foreign) has been gathered and analysed. On the BSE website, information about each shareholder that owns at least $10 \%$ of firm's capital is disclosed, otherwise being included in the category of "other shareholders" (except for the state ownership that is disclosed at any percentage). The proportion of foreign capital out of total (FRN_SHL) was taking into consideration as the variable that will be used to modelling the influence of different cultural background of shareholders. Also, a proxy control variable (AGE) was developed to designate the company's organizational culture based on the number of years since the firm exists in business. Each company has been categorized using its major domain of activity into friendly and non-friendly environment company using a dummy variable (ENV), 
with assigned values of 0 for companies with less polluting activities (such as hotels and restaurants, real estate activities), and 1 for companies whose activity is not environmental friendly (mining and quarrying, manufacturing, transport and storage, construction, etc.)

Secondly, information about board structure was collected: board size, proportion of executive and non-executive directors, Romanian and foreigners, men and women, and also the number of board meetings, because the board is exerting its delegated power and duties during board meetings.

The board structure is an important issue, due to the communication and decisionmaking process that is taking place during board meetings, although the roles and responsibilities of the board may vary depending on the type of business entity. Executive directors are appointed by shareholders and are considered those that were assigned to conduct the companies' operations. Usually, in Romanian companies, they are occupying the position of top manager or financial manager. Non-executive directors are also appointed by shareholders, based on their prestige, connections and experience, but have no roles in conducting daily activities of the company.

Consequently, based on these data, new variables were added to the model: the percentage of foreign board members (FRN_BRD), percentage of executive members of board (EXEC_BRD), the proportion of women in the board (WOM_BRD) and the number of board meetings during each year (MEET). Further on, the management teams structure was analysed and information about the Romanian and foreign managers were gathered, along with gender information and two more variables were set: FRN_MN (as being the proportion of foreigners in the management team) and WOM_MN (representing the proportion of women in the management team).

Financial data for each company were gathered from balance sheets, income statements and the BSE website referring to: fixed and current assets, equity, net sales, earnings before income and taxes, net income, and also market capitalization for calculating various financial indicators of company performance (ROA, ROE, ROS and P/BV). ROA (return on assets), ROE (return on equity), ROS (return on sales) and $\mathrm{P} / \mathrm{BV}$ (price to book ratio) are indicated by the vast majority of researchers as being adequate measures of the financial performance of the companies taking into account the variety of stakeholders that are interested in company's evolution. In the paper they are considered as dependent variables of a regression model that will be developed.

The firm performance in relationship with management team is appropriately expressed by using ROA as the measure, because it represents the operational profits that managers are able to obtain using the company's assets regardless of its financial and fiscal policies. Managers decide how to acquire and use fixed and current assets, what kind of operations to develop and also the type and amount of material and human resources that will be used in the process. Moreover, managers decide the commercial partnerships that the company will enter in and the customers and suppliers characteristics that are beneficial for company's profitability. So, using ROS as a firm performance measurement is also appropriate, because net income and net sales both depend on companies' relationship with customers and suppliers. However, how the company is financed remains one of the main attributes of shareholders, that decide if the company goes in debt or not. Ultimately, the financial structure of the company derives both from shareholders' will and financial markets evolution (via interest rates and exchange ratios). The level and structure of taxation is the state attribute, and companies must comply with and using ROE as an indicator of 
shareholders interest in company's financial performance is relevant under the above circumstances. But for the potential investors that are judging company's results based on market price, a more appropriate measure of performance seems to be $\mathrm{P} / \mathrm{BV}$, that is comparing market perception about company's attractiveness (via market price per share) with the book value of the company (that is to be found in its financial statements).

\section{Results}

\subsection{Descriptive statistics}

According to information obtained from companies and summarized in table 2, data on the ownership structure of companies listed on the BSE shows that there are companies who includes no foreign shareholders, and correspondingly companies where the proportion is over $90 \%(0.9341)$, with an average of $18.21 \%(0.182135)$. The structure of the board of companies is also one variant, either with no foreign board, or composed entirely of foreigners, their average presence in the board being of $16.18 \%$ (0.161771). But foreigners are rather uncommon in the structure of management team, their average percentage being of only $5.86 \%(0.058603)$, lower even than women's participation (17.81\% e.g. 0.178091). Indeed, women are present in the management teams of the companies, but at a much lower proportion than men, and there are cases in which no woman is included in the management team or on the board of some companies. If women are included in the management team, they are usually occupying the CFO position, sales manager or quality manager positions. The newest founded company (of those listed on the stock exchange) has existed for 16 years, but there are companies centenarians, most of them operating rather in the areas with polluting technologies (gas, oil, mining and quarrying).

Table 2. Independent and control variable - Descriptive statistics

\begin{tabular}{|l|r|r|r|r|r|}
\hline & \multicolumn{1}{|c|}{ Range } & \multicolumn{1}{c|}{ Minimum } & Maximum & \multicolumn{1}{c|}{ Mean } & Std. Deviation \\
\hline X1 FRN_SHL & 0.9341 & 0.0000 & 0.9341 & 0.182135 & 0.2969510 \\
X2 FRN_BRD & 1.0000 & 0.0000 & 1.0000 & 0.161771 & 0.3052753 \\
X3 EXEC_BRD & 1.0000 & 0.0000 & 1.0000 & 0.183535 & 0.1768178 \\
X4 WOM_BRD & 0.6667 & 0.0000 & 0.6667 & 0.178091 & 0.2041438 \\
X5 FRN_MN & 1.0000 & 0.0000 & 1.0000 & 0.058603 & 0.1892633 \\
X6 WOM_MN & 1.0000 & 0.0000 & 1.0000 & 0.253197 & 0.2819936 \\
X7SIZE & 9.4475 & 14.0798 & 23.5273 & 18.550120 & 1.9057499 \\
X8 AGE & 109 & 16 & 125 & 56.97 & 27.364 \\
X9 MEET & 65 & 1 & 66 & 10.18 & 10.174 \\
X10 ENV & 1 & 0 & 1 & 0.88 & 0.327 \\
\hline
\end{tabular}




\subsection{Correlations analysis}

Analysing the significant Pearson coefficients presented in table 3 (both for a $95 \%$ and $90 \%$ confidence level), a series of correlations can be observed between the model variables. At $90 \%$ confidence level, the assets profitability $(\mathrm{ROA})$ is strongly and positively correlated with sales profitability, ROS $(0.654)$ and with return on equity ratio, ROE (0.641) and positively but moderate correlated with the price to book ratio, P/BV (0.323).

Also, at $95 \%$ confidence level, ROA is positively weak correlated with the presence of women in the management team, WOM_MN (0.180), with the company's size, SIZE (0.325) and with polluting technologies, ENV (0.184) and weak negatively correlated with the presence of foreigners in boardrooms, FRN_BRD $(-0.197)$. Likewise, ROS is positively (but moderate) correlated with the company's size (0.352) and polluting technologies $(0.223)$ and weakly negative correlated with foreign shareholders $(-0.178)$, foreign board members $(-0.212)$ and their presence in management teams $(-0.198)$, and also with more executives' members in boardrooms $(-0.168)$. ROE is positively but weakly correlated with women's presence in managerial teams $(0.200)$ and weak-negatively with foreign shareholders $(-0.215)$, foreign members in boardrooms $(-0.250)$ and with the appointment of foreign managers $(-0.268)$. On the other hand, foreign shareholders tend to appoint more foreign board members (as 0.641 strong correlation level indicates) but also rather foreign than Romanian managers (as 0.221 correlation level shows). One can see that the higher the company's P/BV ratio is, the bigger the interest of foreign shareholders to own it (a significant 0.264 positive correlation level shows it).

A more diverse board is more inclined to appoint a more diverse management team (to include also foreign managers, as strong correlation coefficient indicates). A board that includes women is more inclined to appoint women in management team, too (at 0.271 , correlation coefficient being significant). It seems that larger companies are positively correlated with a higher number of board meetings, which can be explained through the company's increased complexity of activity (as the positive significant level of 0.393 indicates). And finally, the data shows that larger and older companies included in the study have rather non-environmental friendly technologies (as the correlation coefficients shows).

\subsection{Regression Models}

For a better understanding of the relationship between firm performance and its drivers, after correlation calculus, regression models were built and tested using SPSS.

First, the relationship between ROA and its explicative factors has been tested (see equation 2) and the values of " $\beta$;" coefficient presented, along with the values of $p$ level for $\mathrm{t}$-test, to indicate their relevance for the model (see table 4).Beta coefficients are relevant if corresponding $p$-values are less than 0.05 .

$$
\begin{aligned}
\mathrm{ROA} & =\alpha+\beta_{1} F R N \_S H L+\beta_{2} F R N=B R D+\beta_{3} E X E C\left[B R D+\beta_{4} W O M \_B R D+\beta_{5} F R N \_M N+\right. \\
& +\beta_{6} W O M \_M N+\beta_{7} S I Z E+\bar{\beta}_{8} A G E+\beta_{9} M E E T+\beta_{10} E N V+\xi_{i}
\end{aligned}
$$


Successive iterations were performed in SPSS to test the model's validity, excluding step by step the variables with the highest values of p-level (and greater than 0.05). For all iterations, the values of $R^{2}$, Adjusted $R^{2}$ and Fisher-Snedecor were emphasised to see how well the model fits the data. The higher the $\mathrm{R}^{2}$ and Adjusted $\mathrm{R}^{2}$ values, the more one can rely on selected independent variables to explain the variations in companies' performances. Also Durbin-Watson error autocorrelations were tested to exclude auto-correlation errors of the model.

Taking into account all these aspects, the valid regression model for ROA has been developed, as depicted in equation (3). Similar rationing was performed for ROE, ROS and P/BV, with valid regression models depicted in equations (4) to (6).

$$
R O A=-0.199-0.054 \cdot F R N \_S H L+0.054 \cdot W O M \_M N+0.013 \cdot S I Z E
$$

Valid model for ROE is confirming the identified link between ROE and the ownership structure and also between ROE and the presence of foreign managers in the management team (both pairs being found negatively correlated as data in table 3 indicated, too). The presence of women in the management team, on the other hand, seems to confirm the positive influence that the correlation coefficient has previously indicated in calculations from table 3. ROE is increasing with the company's size, as well.

$$
\text { ROE }=-0.094 \cdot F R N \_S H L-0.141 \cdot F R N \_M N+0.090 \cdot W O M \_M N+0.002 \cdot S I Z E
$$

The statistical significant coefficients indicate that an increase in sales profitability is negatively influenced by the presence of foreign shareholders in the ownership structure and also by the presence of executive members of the board, but positively by the presence of women in the managerial team. And this is more visible if the company is larger - see equation (5).

$$
\text { ROS }=-0.629-0.172 \cdot F R N \_S H L-0.162 \cdot E X E C \_B R D+0.130 \cdot W O M \_M N+0.037 \cdot S I Z E
$$

But the market perception regarding firm's value compared with the book one is telling a different story. The presence of foreign shareholders seems to contribute to an increase in the company's market image, and this is observable with increasing the company's size - see equation (6).

$$
\mathrm{P} / \mathrm{BV}=0.788 \cdot F R N \_S H L-0.515 \cdot F R N \_B R D+0.039 \cdot S I Z E
$$

\subsection{The main findings}

The main findings of the regression analysis shows that the ownership structure (FRN_SHL) has significant negative influence on the accounting measure of assets profitability (ROA) and equity (ROE), but especially on sales profitability (ROS), hence a positive influence on P/BV. From table 3 we can see that a correlation between company's performance (in terms of sales and equity) and the ownership structure 
exist and is slightly negative (correlation level -0.178 respectively -0.215 ), but positive in term of market to book value ratio (0.264). Zeitun and Tian (2007) also noticed that such effects exist, while other researchers find rather positive influences. A possible explanation is that some studies were conducted on developed markets, while others on emergent markets, such as the present one with different history of existence and cultural background.

If the board is including executive members (that are appointed as CEOs for those companies), their influence tends not to be beneficial for increasing sales profitability (as the negative coefficient of -0.162 in equation (5) indicate), having however no effect on ROA, ROE and P/BV, and being coherent with similar findings of Vintilă and Gherghina (2013) on the same market.

The presence of foreign managers influences only ROE, by diminishing it (by -0.141 times) when they are included in the management team. Companies seem to benefit from women's presence in the management team, but not in the boardrooms, as the regression equations coefficients of WOM_MN show in relations (3), (4) and (5). Smith et al. (2006) found similar results on a panel of Danish companies, and also Dezso and Ross (2012), but more recent research on Vietnamese financial market by Nguyen et al. (2015) indicated the existence of such relationship in transitional economies characterized by an underdeveloped corporate governance system, especially when the number of women in boardroom increase. For the board of directors, the presence of one or two foreign persons or of women is not enough to make it sufficiently diverse and therefore to remarkably influence the firm's performance. Same results were also obtained by Charles et al. (2015) indicating that unless there are at least three women on board, their presence has an insignificant effect on firm performance.

But there is a positive influence coming from the company's size: the bigger the company is, the better the chances are to have high performances, even if their board is having frequent or less frequent meetings or their activity is more or less polluting. And if they, additionally, appoint women in managerial positions, the company's performance is even significant.

\section{Conclusions}

The paper considered panel data analysis from the period 2014-2015 on the Romanian financial market, being among the first of its kind in the field on this market that addresses both cultural and gender diversity correlated with the financial performance of companies.

The research conducted is useful for many categories of users. First, it can be used by shareholders in order to make better investment decisions, when it comes to find best criteria for future investments. Secondly, the results can be used by the BSE board for improving the Code of Corporate Governance regarding ownership and board structure and behaviour. Thirdly, universities policy-makers can encourage more women to study business administration, because their contributions to firms' performances tend to be more appreciated. And finally, governmental policy-makers can use the results for a better adjustment of social, educational and economic policies, based on the fact that diversity in gender and culture can lead to positive results. 
The descriptive statistics of the gathered data indicated that some companies have no foreign shareholders; while others are over $90 \%$ owned by foreigners, but the average foreign ownership is slightly over $18 \%$. The boards of the analysed companies can include either no foreign managers or can be entirely constituted by foreign members, with an average level of $16.18 \%$. But foreigners are rather uncommon in the structure of management team, their average percentage being of only $5.86 \%$ lower even than women's participation (17.81\%). If women are to participate in companies' management, usually they are not in top positions (as top manager or similar), but in the position of CFO, sales managers or quality managers. We consider that supplementary encouragement for considering managerial career for women should be encouraged, because their contributions to companies start to become more significant.

Correlation analysis results from table 3 and regression models developed (see relations (3) to (6)) indicate that a direct relationship between all financial performance ratios and a diverse cultural shareholder, boards and management structure exists, but is not a strong one. The return on assets, sales and equity ratios are rather negatively influenced by the presence of foreign shareholders, while the $\mathrm{P} / \mathrm{BV}$ is positively influenced. The presence of women in the management teams also tend to have positive influence on companies' performances, regardless of the companies' age in business, but correlated with their size. Larger companies tend to appoint more women in managerial positions, but not in their boards, regardless of the domain of activity.

The firm performance (in terms of $\mathrm{P} / \mathrm{BV}$ ) is indeed influenced by the presence of foreign members of the board and foreign ownership, but the accounting values of financial performance (ROA, ROE, ROS) are not sensitive to such cultural influence, nor to a gender diverse board structure, only to board independence (ROS case) and to gender structure of managerial teams (ROA, ROE and ROS cases).

Moreover, the study revealed that boards that are culturally diverse are more inclined to appoint foreign managers and women in firm's managerial teams, but because of the small number of such persons, we cannot say that this can be strongly positive associated with an increased financial performance of the firm.

The results obtained are mixt, equations (3) to (6) showing that relationships exist, but the influence of the analysed variables on companies performance need to be analysed in a future study on a longer period of time to a better understanding of their evolution and behaviour.

Likewise, taking into consideration the obtained results, further investigations should be made in order to detect also a possible relationship of performance in line with certain fiscal behaviour of shareholders, because many of the listed companies are registered in fiscal paradises such as Cyprus, Cayman Islands and Luxembourg (22.4\% of listed BSE companies), only $15.5 \%$ having foreign shareholders registered in Austria, Germany, Greece, Netherland, Saudi Arabia or US, and the rest being registered in Romania.

But, in the end, giving the fact that we are living in a more complex, competitive and multi-cultural world, with more learning opportunities both for men and women, but also living in a more challenging environment, the policy-makers should take into consideration that a more gender and cultural diverse ownership board and management team can contribute to the increase of companies performance. 


\section{References}

Abukosim, Mukhtaruddin, Ferina, I. S., Nurcahaya, C. (2014) Ownership structure and firm values: empirical study on Indonesia manufacturing listed companies, Researchers World, 5(4): 1-14.

Aydin, N., Sayim M., Yalama, M. (2007) Foreign Ownership and Firm Performance: Evidence from Turkey, International Research Journal of Finance and Economics, 11: 103-110.

Baumol, W., J. (1959), Business Behavior Value and Growth. New York: Macmillan

Carter, D.A.; Simkins B.J.; Simpson W.G. (2003) Corporate governance, board diversity and firm value, The Financial Review, 38: 33-53.

Charles, A., Redor, E., Zopunidis, C. (2015) The determinants of the existence of a critical mass of women on boards: A discriminant analysis, Economics Bulletin, 35(3): 1809-1819.

Chidambaran, N. K., Palia, D., \& Zheng, Y. (2008) Corporate governance and firm performance: Evidence from large governance changes, Available at SSRN http://ssrn.com/abstract=1108497 (referred on 09/04/2016)

Claessens, S., Tsioumis, K. (2006) Ownership and Financing Structures of Listed and Large Non-listed Corporations, Corporate Governance: An International Review, 14(4): 266-276.

Cull, R., Xu, I., C. (2005) Institutions, ownership, and finance: the determinants of profit reinvestment among Chinese firms, Journal of Financial Economics, 77(1): 117-146.

Cyert, R., M., March, J.,G. (1963) A behavioural theory of the firm. New Jersey: PrenticeHall.

Darko, J., Aribi, Z. A., Uzonwanne, G. C. (2016) Corporate governance: the impact of director and board structure, ownership structure and corporate control on the performance of listed companies on the Ghana stock exchange, Corporate Governance: The International Journal of Business in Society, 16(2): 259-277.

Dezso, C., L., Ross, D., G. (2012) Does Female Representation in Top Management Improve Firm Performance? A Panel Data Investigation, Strategic Management Journal, 33(9): 1072-1089.

Erhardt, N.L., Werbel, J., D., Shrader, Ch. B. (2003) Board of Director Diversity and Firm Financial Performance, Corporate Governance: An International Review, 11(2): 102-111.

Ferreira, D., Kirchmayer, T. (2013) Corporate boards in Europe: size, independence and gender diversity, in Belcredi, M., Ferrarini, G. (Eds.). Boards and Shareholders in European Listed Companies. Facts, Context and Post-Crisis Reforms, UK: Cambridge University Press: 191-223.

Fitzsimmons, J.,R., Steffens, P.,R., Douglas, E., J. (2005), Growth and profitability in small and medium sized Australian firms, Proceedings AGSE Entrepreneurship Exchange, Melbourne.

Hofstede, G. (1983) Culture's Consequences: International Differences in Work-Related Values, Administrative Science Quarterly, 28(4): 625-629.

Huselid, M. A., Jackson, S. E., Schuler, R. S. (1997) Technical and strategic human resources management effectiveness as determinants of firm performance, Academy of Management Journal, 40(1): 171-188. 
Jensen, M., C. (1993) The modem industrial revolution, exit, and the failure of internal control systems, Journal of Finance, 48: 831-880.

Julizaerma, M. K., Sori, Z. M. (2012) Gender diversity in the boardroom and firm performance of Malaysian public listed companies, Procedia-Social and Behavioral Sciences, 65: 1077-1085.

Lin, Chin Shien., Chang, Ruei Yuan., Dang, Van Thac. (2015) An Integrated Model to Explain How Corporate Social Responsibility Affects Corporate Financial Performance, Sustainability, 7: 8292-8311.

Nguyen, T., Locke, S., Reddy, L. (2015) Does boardroom gender diversity matter? Evidence from a transitional economy, International Review of Economics \& Finance, 37: 184-202.

Moscu, R., G. (2015) Study on correlation between CEO duality and corporate performance of companies listed on the Bucharest Stock Exchange, Journal of Social and Economic Statistics, 4(1): 2015, 46-53.

Roberge, M-E., van Dick R. (2010) Recognizing the benefits of diversity: When and how does diversity increase group performance?, Human Resource Management Review, 20: 295-308.

Richard,O.C.(2000) Racial diversity, business strategy, and firm performance: A resource-based view", The Academy of Management Journal,43: 164-177.

Rodríguez-Domínguez, L., García-Sánchez, I., \& Gallego-Álvarez, I. (2012) Explanatory factors of the relationship between gender diversity and corporate performance, European Journal of Law and Economics, 33(3): 603-620.

Santos, J., B., Brito, L., A. (2012) Toward a Subjective Measurement Model for Firm Performance, Brazilian Administration Review, 9(6): 95-117.

Smith, N., Smith, V., Verner, M. (2006) Do women in top management affect firm performance? A panel study of 2500 Danish firms, International Journal of Productivity and Performance Management, 55(7): 569-593.

Torres-Reyna, O. (2007) Panel data analysis fixed and random effects using Stata (v. 4.2), Data \& Statistical Services, Priceton University

Van Knippenberg, D., \& Schippers, M. C. (2007) Work group diversity, Annual Review of Psychology, 58: 515-541.

Vintilă, G., Gherghina, S., C. (2015) Does ownership structure influence firm value? An empirical research towards the Bucharest Stock Exchange listed companies", International Journal of Economics and Financial Issues, 5(2): 501-514.

Vintilă, G., Gherghina, S.,C. (2013) Board of Directors Independence and Firm Value: Empirical Evidence Based on the Bucharest Stock Exchange Listed Companies", International Journal of Economics and Financial Issues,3(4):885-900.

Zeitun, R., Tian, G. G. (2007) Does ownership affect a firm's performance and default risk in Jordan?", Corporate Governance, 7(1): 66-82.

Zhen Zeng, (2011) The myth of the glass ceiling: Evidence from a stock-flow analysis of authority attainment", Social Science Research, 40(1): 312-325. 
Table 3. Correlation coefficients

\begin{tabular}{|c|c|c|c|c|c|c|c|c|c|c|c|c|c|}
\hline $\begin{array}{c}\text { Correla- } \\
\text { tion } \\
\text { matrix }\end{array}$ & Y2 & Y3 & Y4 & X1 & X2 & X3 & $X 4$ & X5 & X6 & $\mathrm{X} 7$ & $\mathrm{X} 8$ & X9 & $\mathrm{X} 10$ \\
\hline $\begin{array}{l}\text { Y1 } \\
\text { ROA }\end{array}$ & $\begin{array}{l}.654^{* *} \\
(.000)\end{array}$ & $\begin{array}{l}.641^{*+} \\
(.000)\end{array}$ & $\begin{array}{l}.323^{+*} \\
(.000)\end{array}$ & $\begin{array}{l}-.145 \\
(.060)\end{array}$ & $\begin{array}{l}-.197^{*} \\
(.017)\end{array}$ & $\begin{array}{c}.034 \\
(.359)\end{array}$ & $\begin{array}{l}-.039 \\
(.339)\end{array}$ & $\begin{array}{l}-.089 \\
(.172)\end{array}$ & $\begin{array}{l}.180^{*} \\
(.026)\end{array}$ & $\begin{array}{l}.325^{*} \\
(.000)\end{array}$ & $\begin{array}{c}.036 \\
(.350)\end{array}$ & $\begin{array}{c}.046 \\
(.311)\end{array}$ & $\begin{array}{l}.184^{*} \\
(.024)\end{array}$ \\
\hline $\begin{array}{l}\text { Y2 } \\
\text { ROS }\end{array}$ & & $\begin{array}{l}.533^{* *} \\
(.000)\end{array}$ & $\begin{array}{l}-.088 \\
(.175)\end{array}$ & $\begin{array}{l}-.178^{*} \\
(.028)\end{array}$ & $\begin{array}{l}-.212^{*} \\
(.011)\end{array}$ & $\begin{array}{l}-.168^{*} \\
(.036)\end{array}$ & $\begin{array}{l}-.085 \\
(.183)\end{array}$ & $\begin{array}{l}-.198^{*} \\
(.017)\end{array}$ & $\begin{array}{c}.125 \\
(.091)\end{array}$ & $\begin{array}{l}.352^{+*} \\
(.000)\end{array}$ & $\begin{array}{c}.105 \\
(.131)\end{array}$ & $\begin{array}{c}.134 \\
(.075)\end{array}$ & $\begin{array}{l}.223^{*} \\
(.008)\end{array}$ \\
\hline $\begin{array}{l}\text { Y3 } \\
\text { ROE }\end{array}$ & & & $\begin{array}{l}.054 \\
.283\end{array}$ & $\begin{array}{l}-.215^{*} \\
(.010)\end{array}$ & $\begin{array}{l}-.250^{* *} \\
(.003)\end{array}$ & $\begin{array}{c}.028 \\
(.384)\end{array}$ & $\begin{array}{c}.060 \\
(.263)\end{array}$ & $\begin{array}{l}-.268^{* *} \\
(.002)\end{array}$ & $\begin{array}{l}.200^{*} \\
(.016)\end{array}$ & $(.102)$ & (.392) & $\begin{array}{l}-.064 \\
(.248)\end{array}$ & $\begin{array}{c}.115 \\
(.109)\end{array}$ \\
\hline $\begin{array}{l}\text { Y4 } \\
\text { P/BV }\end{array}$ & & & & $\begin{array}{l}.264^{* *} \\
(.002)\end{array}$ & $\begin{array}{l}.241^{* *} \\
(.005)\end{array}$ & $\begin{array}{l}.166^{\star} \\
(.037)\end{array}$ & $\begin{array}{l}-.053 \\
(.285)\end{array}$ & $\begin{array}{c}.162^{*} \\
(.041)\end{array}$ & $\begin{array}{c}.013 \\
(.445)\end{array}$ & $\begin{array}{c}.030 \\
(.373)\end{array}$ & $\begin{array}{l}-.028 \\
(.384)\end{array}$ & $\begin{array}{c}.003 \\
(.488)\end{array}$ & $\begin{array}{l}-.131 \\
(.080)\end{array}$ \\
\hline $\begin{array}{l}\text { X1 } \\
\text { FRN_ } \\
\text { SHL }\end{array}$ & & & & & $\begin{array}{l}.641^{* *} \\
(.000)\end{array}$ & $\begin{array}{l}-.049 \\
(.299)\end{array}$ & $\begin{array}{l}-.131 \\
(.080)\end{array}$ & $\begin{array}{l}.221^{\text {** }} \\
(.009)\end{array}$ & $\begin{array}{c}.124 \\
(.093)\end{array}$ & $\begin{array}{l}.233^{* *} \\
(.006)\end{array}$ & $\begin{array}{l}-.110 \\
(.119)\end{array}$ & $\begin{array}{c}.019 \\
(.419)\end{array}$ & $\begin{array}{c}.020 \\
(.417)\end{array}$ \\
\hline $\begin{array}{l}\text { X2 } \\
\text { FRN_ } \\
\text { BRD }\end{array}$ & & & & & & $\begin{array}{l}-.059 \\
(.263)\end{array}$ & $\begin{array}{l}-.155^{\star} \\
(.048)\end{array}$ & $\begin{array}{l}.617^{* *} \\
(.000)\end{array}$ & $\begin{array}{c}.023 \\
(.403)\end{array}$ & $\begin{array}{c}.014 \\
(.440)\end{array}$ & $\begin{array}{l}-.102 \\
(.139)\end{array}$ & $\begin{array}{l}-.078 \\
(.203)\end{array}$ & $\begin{array}{c}.023 \\
(.403)\end{array}$ \\
\hline $\begin{array}{l}\text { X3 } \\
\text { EXEC } \\
\text { BRD }\end{array}$ & & & & & & & $\begin{array}{c}.108 \\
(.124)\end{array}$ & $\begin{array}{c}.076 \\
(.208)\end{array}$ & $\begin{array}{c}.102 \\
(.137)\end{array}$ & $\begin{array}{l}-.066 \\
(.241)\end{array}$ & $\begin{array}{l}-.132 \\
(.079)\end{array}$ & $\begin{array}{l}-.120 \\
(.100)\end{array}$ & $\begin{array}{l}-.077 \\
(.206)\end{array}$ \\
\hline $\begin{array}{l}\text { X4 } \\
\text { WOM } \\
\text { BRDD }\end{array}$ & & & & & & & & $\begin{array}{l}-.060 \\
(.262)\end{array}$ & $\begin{array}{l}.271^{* *} \\
(.002)\end{array}$ & $\begin{array}{l}-.133 \\
(.077)\end{array}$ & $\begin{array}{l}-.086 \\
(.179)\end{array}$ & $\begin{array}{l}-.062 \\
(.253)\end{array}$ & $\begin{array}{l}-.086 \\
(.180)\end{array}$ \\
\hline $\begin{array}{l}\text { X5 } \\
\text { FRN_ } \\
\text { MN }\end{array}$ & & & & & & & & & $\begin{array}{l}-.121 \\
(.098)\end{array}$ & $\begin{array}{l}-.030 \\
(.376)\end{array}$ & $\begin{array}{l}-.143 \\
(.063)\end{array}$ & $\begin{array}{l}-.094 \\
(.158)\end{array}$ & $\begin{array}{l}-.072 \\
(.221)\end{array}$ \\
\hline $\begin{array}{l}\text { X6 } \\
\text { WOM } \\
\text { MN }\end{array}$ & & & & & & & & & & $\begin{array}{l}-.104 \\
(.133)\end{array}$ & $\begin{array}{l}-.127 \\
(.088)\end{array}$ & $\begin{array}{l}-.152 \\
(.052)\end{array}$ & $\begin{array}{l}-.125 \\
(.091)\end{array}$ \\
\hline $\begin{array}{l}\text { X7SIZ } \\
\mathrm{E}\end{array}$ & & & & & & & & & & & $\begin{array}{c}.036 \\
(.351)\end{array}$ & $\begin{array}{l}.393^{* *} \\
(.000)\end{array}$ & $\begin{array}{l}.261^{*} \\
(.002)\end{array}$ \\
\hline $\begin{array}{l}\text { X8 } \\
\text { AGE }\end{array}$ & & & & & & & & & & & & $\begin{array}{c}.039 \\
(.337)\end{array}$ & $\begin{array}{l}.247^{+*} \\
(.004)\end{array}$ \\
\hline $\begin{array}{l}\text { X9 } \\
\text { MEET }\end{array}$ & & & & & & & & & & & & & $\begin{array}{l}-.004 \\
(.484)\end{array}$ \\
\hline
\end{tabular}

** - Correlation is significant at 0.01 level (Sig. 1-tiled)

* - Correlation is significant at 0.05 level (Sig. 1-tiled) 
Table 4 - Drivers of asset profitability (ROA)

\begin{tabular}{|c|c|c|c|c|c|c|c|c|c|c|c|c|c|c|}
\hline \multirow[b]{2}{*}{ ర్ષ } & \multicolumn{11}{|c|}{ Coefficients (value of $p$ level for t-test) } & \multirow[b]{2}{*}{ 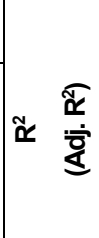 } & \multirow{2}{*}{\multicolumn{2}{|c|}{ 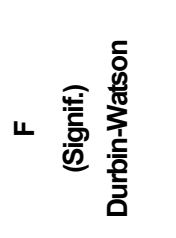 }} \\
\hline & $\begin{array}{l}\overrightarrow{0} \\
\text { ठั }\end{array}$ & 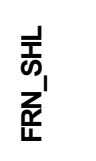 & 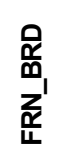 & $\begin{array}{l}\text { 足 } \\
\text { |' } \\
\text { 岁 } \\
\text { 离 }\end{array}$ & 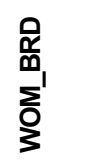 & $\begin{array}{l}z \\
z_{1} \\
z_{1} \\
\underline{u}\end{array}$ & $\begin{array}{l}\text { Z } \\
\sum_{0}^{1} \\
\text { O }\end{array}$ & $\begin{array}{l}\text { 山 } \\
\text { ๗ }\end{array}$ & 岁 & 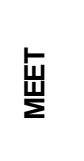 & $\sum_{\text {出 }}$ & & & \\
\hline \#1 & $\begin{array}{l}-.196 \\
(.001)^{\star}\end{array}$ & $\begin{array}{l}-.040 \\
(.098)\end{array}$ & $\begin{array}{l}-.032 \\
(.265)\end{array}$ & $\begin{array}{c}.005 \\
(.862)\end{array}$ & $\begin{array}{l}-.031 \\
(.230)\end{array}$ & $\begin{array}{c}.031 \\
(.391)\end{array}$ & $\begin{array}{c}.061 \\
(.002)^{\star}\end{array}$ & $\begin{array}{c}.012 \\
(.000)^{\star}\end{array}$ & $\begin{array}{r}-.000 \\
(.989)\end{array}$ & $\begin{array}{r}.000 \\
(.487)\end{array}$ & $\begin{array}{c}.023 \\
(.174)\end{array}$ & $\begin{array}{c}.257 \\
(.187)\end{array}$ & $\begin{array}{l}3.640 \\
(.000)\end{array}$ & 1.921 \\
\hline \#2 & $\begin{array}{l}-.196 \\
(.000)^{\star}\end{array}$ & $\begin{array}{l}-.040 \\
(.096)\end{array}$ & $\begin{array}{l}-.032 \\
(.263)\end{array}$ & $\begin{array}{r}.005 \\
(.859)\end{array}$ & $\begin{array}{l}-.031 \\
(.227)\end{array}$ & $\begin{array}{c}.031 \\
(.386)\end{array}$ & $\begin{array}{c}.061 \\
(.002)^{\star}\end{array}$ & $\begin{array}{c}.012 \\
(.000)^{\star}\end{array}$ & & $\begin{array}{r}.000 \\
(.485)\end{array}$ & $\begin{array}{c}.022 \\
(.162)\end{array}$ & $\begin{array}{c}.257 \\
(.194)\end{array}$ & $\begin{array}{l}4.083 \\
(.000)\end{array}$ & 1.920 \\
\hline \#3 & $\begin{array}{l}-.195 \\
(.000)^{\star}\end{array}$ & $\begin{array}{l}-.040 \\
(.095)\end{array}$ & $\begin{array}{l}-.032 \\
(.249)\end{array}$ & & $\begin{array}{l}-.031 \\
(.228)\end{array}$ & $\begin{array}{c}.032 \\
(.365)\end{array}$ & $\begin{array}{c}.062 \\
(.001)^{\star}\end{array}$ & $\begin{array}{c}.012 \\
(.000)^{\star}\end{array}$ & & $\begin{array}{r}.000 \\
(.470)\end{array}$ & $\begin{array}{r}.022 \\
(.162)\end{array}$ & $\begin{array}{c}.257 \\
(.202)\end{array}$ & $\begin{array}{l}4.631 \\
(.000)\end{array}$ & 1.921 \\
\hline$\# 4$ & $\begin{array}{l}-.185 \\
(.000)^{*}\end{array}$ & $\begin{array}{l}-.039 \\
(.100)\end{array}$ & $\begin{array}{l}-.033 \\
(.243)\end{array}$ & & $\begin{array}{l}-.031 \\
(.224)\end{array}$ & $\begin{array}{c}.034 \\
(.328)\end{array}$ & $\begin{array}{c}.064 \\
(.001)^{\star}\end{array}$ & $\begin{array}{c}.011 \\
(.000)^{\star}\end{array}$ & & & $\begin{array}{c}.024 \\
(.129)\end{array}$ & $\begin{array}{c}.254 \\
(.205)\end{array}$ & $\begin{array}{l}5.241 \\
(.000)\end{array}$ & 1.909 \\
\hline \#5 & $\begin{array}{l}-.185 \\
(.000)^{\star}\end{array}$ & $\begin{array}{c}-.046 \\
(.048)^{\star}\end{array}$ & $\begin{array}{l}-.015 \\
(.478)\end{array}$ & & $\begin{array}{l}-.029 \\
(.253)\end{array}$ & & $\begin{array}{c}.061 \\
(.001)^{\star}\end{array}$ & $\begin{array}{c}.011 \\
(.000)^{\star}\end{array}$ & & & $\begin{array}{c}.022 \\
(.162)\end{array}$ & $\begin{array}{c}.247 \\
(.205)\end{array}$ & $\begin{array}{l}5.995 \\
(.000)\end{array}$ & 1.894 \\
\hline \#6 & $\begin{array}{l}-.193 \\
(.000)^{*}\end{array}$ & $\begin{array}{l}-.056 \\
(.001)^{\star}\end{array}$ & & & $\begin{array}{l}-.028 \\
(.277)\end{array}$ & & $\begin{array}{c}.061 \\
(.001)^{\star}\end{array}$ & $\begin{array}{c}.012 \\
(.000)^{\star}\end{array}$ & & & $\begin{array}{c}.021 \\
(.172)\end{array}$ & $\begin{array}{c}.243 \\
(.209)\end{array}$ & $\begin{array}{l}7.076 \\
(.000)\end{array}$ & 1.961 \\
\hline \#7 & $\begin{array}{l}-.201 \\
(.000)^{\star}\end{array}$ & $\begin{array}{c}-.053 \\
(.002)^{*}\end{array}$ & & & & & $\begin{array}{c}.056 \\
(.002)^{\star}\end{array}$ & $\begin{array}{c}.012 \\
(.000)^{\star}\end{array}$ & & & $\begin{array}{c}.022 \\
(.161)\end{array}$ & $\begin{array}{c}.235 \\
(.208)\end{array}$ & $\begin{array}{l}8.532 \\
(.000)\end{array}$ & 1.952 \\
\hline \#8 & $\begin{array}{l}-.199 \\
(.000)^{\star}\end{array}$ & $\begin{array}{c}-.054 \\
(.002)^{\star}\end{array}$ & & & & & $\begin{array}{c}.054 \\
(.003)^{\star}\end{array}$ & $\begin{array}{c}.013 \\
(.000)^{\star}\end{array}$ & & & & $\begin{array}{c}.221 \\
(.201)\end{array}$ & $\begin{array}{l}10.619 \\
(.000)\end{array}$ & 1.969 \\
\hline
\end{tabular}

Note: * - indicate $p<0.05$ ( $p$-level are in parentheses) 